\title{
COMPONENTS, CRITERIA, INDICATORS AND LEVELS OF PROFESSIONAL COMPETENCE FORMATION OF FUTURE FITNESS-TRAINERS AT HIGHER EDUCATIONAL INSTITUTIONS
}

\author{
Maryna Vasylenko \\ National University of Physical Education and Sport of Ukraine \\ 1 Fizkultury str., Kyiv, Ukraine, 03150 \\ m_vasilenko@ukr.net \\ Myroslav Dutchak \\ National University of Physical Education and Sport of Ukraine \\ 1 Fizkultury str., Kyiv, Ukraine, 03150 \\ mvd21@ukr.net
}

\begin{abstract}
The article considers the problem of estimating the professional competence of future fitness-trainers in higher educational institutions. There was determined the ambiguity of scientific views on the structure of the professional competence of a graduate, considered in the aspect of functional components of activity, management functions, psychic functions and psychological content of activity. There was elaborated the structure of professional competence of future fitness-trainers that includes: motivational, axiological, gnoseological, praxeological and personal components. There were separated the criteria of estimating of professional competence formation of future fitness-trainers: motivational-volitional, value-sense, cognitive-intellectual, operational-technological and socio-psychological ones. The correspondent indicators included: manifestations of volitional self-regulation and professional directionality of a person; striving for self-actualization; volume of knowledge from the cycle of professional subjects and research abilities; degree of didactic-motor, projecting-designing, control-analytic, organizational-regulative, motivational-communicative and marketing-commercial subcompetences; formation of empathy, communicative, organizational, leader abilities and conflict-resistance of a person. There were characterized the high, middle and low levels of the professional competence formation of future fitness-trainers in higher educational institutions.
\end{abstract}

Keywords: fitness-trainer, higher educational institution, professional competence, criterion, indicator.

\section{Introduction}

In the last years the healthy life style gains importance in the population's value system of the world and especially in Europe. According to Karsten Hollasch, the partner of Deloitte Sports Business Group, Europe is the most market of fitness-services in the world. The European association of health and fitness EuropeActive, predicts the growth of the number of members of fitness-cubs up to 80 million persons till 2025 [1]. According to studies of Recruitment \& Employment Confederation - REC, the specialty "fitness-trainer" is in the rating of first twenty high demanded specialties [2]. The increase of demand for qualified specialists needs the formation and development of the effective system of training staff, corresponding to modern requirements. The training system of future fitness-trainers in higher educational institutions has started and develops in European countries and USA [3, 4].

One of main components of professional training is its result and diagnostic instruments. Taking into account the strategy of the competence approach, learning results must be formulated in terms of competences [5].

For understanding results of the professional training of future fitness-trainers in higher educational institutions distinctly, it is necessary to understand the professional competence structure, specificity of fitness-trainer's activity, requirements, set by employers to such specialists in detail. It allows to separate criteria and levels for estimating education results.

It is well-known, that the key characteristic of the notion "professional competence" is an integrative quality of a personality of a future specialist that potentially provides executing his/her 
professional duties and is a result of higher education [6]. We understand that a professional competence as a personal phenomenon has its structure.

The analysis of the scientific literature testifies that there are different approaches to classification of types and components of a professional competence. Thus, researchers separate special, social, personal and individual competence [7]; cognitive, praxeological and axiological components [8]; cognitive, functional, social and meta-components [9]. In the project «Tuning Educational Structures in Europe 2012 - TUNING» authors separate key general and subject-special competences [10].

Let's consider works of scientists, devoted to the specificity of the professional competence of specialists on physical culture and sport and especially fitness-trainers. In the structure of competences of a trainer in sports aerobics the authors separate motivational, personal, informational, operational and motor [11], and in one of competences of a future trainer in athletic gymnastics - motivational, cognitive, behavior, value-sense and emotional-volitional components [12]. Components of the professional competence of future teachers of physical culture for implementing healthy fitness technologies include: motivational-value, cognitive, activity ones of readiness [13]; components of the professional competence of future teachers of physical culture for training healthy gymnastics with girls of senior classes - motivational, cognitive and operational-activity ones of readiness [14]. As to specialists in fitness and recreation, the following structural components are described in literature: motivational-value; content; activity and creative components [15]. Generalizing all aforesaid, we can state, that most researchers name the operational (activity) component of the professional competence that reflects the functional aspect of the specialist's activity.

Pedagogical literature relates the gnostic, projective, organizational, designing, communicative and didactic functions to ones of a trainer in sports aerobics [11]; to ones of a gym coach subject-professional, communicative, commercial, analytic-reflexive, image-presenting functions [16]. According to the authors, types of the fitness-trainer's professional activity include: psychological-pedagogical, gnostic, projecting, designing, communicative, organizational, physical training-health improving, scientific-research, diagnostic, motor and acmeological [17, 18].

The National Strength and Conditioning Association - NSCA of the USA accepted the following list of professional duties of a personal trainer (fitness-trainer):

1) uses an individual approach for estimating, motivating, teaching and training practicing persons, taking into account their needs, connected with changes of their health condition or physical readiness;

2) elaborates safe and effective programs of applying exercises, gives a first help if necessary and guides over persons for achieving their personal tasks.

At the same time it is noted, that personal trainer's duties include motivating persons for the regular motor activity [19].

So, generalizing the aforesaid, we can make a conclusion that there is no integral system theory as to the structure of the professional competence of future fitness-trainers and approaches to diagnosing training results of future fitness-trainers in higher educational institutions are not determined. It conditioned the topicality of the chosen problematics.

\section{Aim of research}

To substantiate components, criteria, indicators and formation levels of the professional competence of future fitness-trainers in higher educational institutions.

\section{Materials and methods of research}

The method of system analysis; analysis and generalization of scientific literature, comparison and confrontation were used for conducting the study.

\section{Results of the research and discussion of the results}

Taking into account theoretical works of scientists and own experience, we have elaborated the structure of the professional competence of future fitness-trainers, formed in higher educa- 
tional institutions including: motivational, axiological, gnoseological, praxeological and personal components.

Let's note that the separated structure of the professional competence of future fitness-trainers differs from one from the scientific literature [15, 17], by both component composition and sense content.

The initial positions at structuring the professional competence of future fitness-trainers in higher educational institutions are the fact that each component in the totality characterizes a certain property, ability or talent of a person that is a direct or indirect base for the successful realization of professional functions.

Let's characterize these components with correspondent criteria, indicators of their estimation (Table 1).

\section{Table 1}

Components, criteria and indicators of the professional competence of future fitness-trainers

\begin{tabular}{|c|c|c|}
\hline Components & Criteria & Indicators \\
\hline \multirow{2}{*}{ Motivational } & \multirow{2}{*}{ Motivational-volitional } & Professional directionality of a person \\
\hline & & Formation of volitional self-regulation \\
\hline Axiological & Value-sense & Striving of a person for self-actualization \\
\hline \multirow[t]{2}{*}{ Gnoseological } & \multirow[t]{2}{*}{ Cognitive-intellectual } & $\begin{array}{l}\text { Presence of the system of base and special knowledge on the cycle of profes- } \\
\text { sional and training subjects }\end{array}$ \\
\hline & & Formation of research abilities \\
\hline Praxeological & Operational-technological & $\begin{array}{l}\text { Formation of didactic-motor, projecting-designing, control-analytic, organi- } \\
\text { zational-regulative, motivational-communicative and marketing-commercial } \\
\text { subcompetences }\end{array}$ \\
\hline Personal & Socio-psychological & $\begin{array}{l}\text { Formation of empathy, communicative, organizational, leader abilities and } \\
\text { conflict-resistance }\end{array}$ \\
\hline
\end{tabular}

The motivational component of the professional competence of future fitness-trainers is characterized by the formation of the personal professional directionality that influences the professional choice, professional self-determination, self-realization, stimulates the cognitive interest of students at studying, professional activity after its finish and is manifested in the integration of motivational constructions and volitional qualities of a specialist's personality. We have separated the motivational-volitional criterion for determining the formation level of the motivational component of the professional competence of future fitness-trainers. It determines a degree of the motivational-volitional criterion, manifested in striving for mastering professional knowledge and skills, working as a fitness-trainer and controlling own behavior in different situations, manage own actions, desires, states consciously.

The indicators of the motivational-volitional criterion are the professional directionality of a person and his/her volitional self-regulation (manifestation of persistence and self-control). Let's note that scientists left beyond attention the importance of volitional self-regulation at substantiating the motivational component of the fitness-trainer's professional competence.

At the same time many similar works underestimate the importance of the worldview aspect of a future specialist's personality $[15,17]$. So, we separated the axiological component of the fitness-trainer's professional competence, based on values of self-actualization that determines the person's ability to self-determination, setting aims, achieving the professional "acme" and actualization of own potentials as means of life sense realization.

From our point of view, the formational of the axiological components of the future fitness-trainer's professional competence are estimated by the value-sense criterion. It allows to determine a maturity degree of a future fitness-trainer, provided by existential values, adequacy of self-estimation, creative attitude to reality and so on. The person's striving for self-actualization was related to the indicator of this criterion. 
The gnoseological component of the professional competence of future fitness-trainers, formed in higher educational institutions, is characterized by the system of general and professional knowledge and formed academic abilities, especially research ones, which totality provides the high level of cognitive activity. This component is estimated by the cognitive-intellectual criterion. It reflects the level of theoretical readiness of students in professional subjects, based on the essential volume of fundamental natural and social knowledge and the development degree of research abilities that provide such rational operations as analysis, synthesis, generalization, differentiation, abstraction, concretization, comparison and analogue, establishment of casual correlations.

The cognitive-intellectual criterion is presented by two indicators: formation of base and special knowledge from the cycle of professional and practical disciplines and one of research abilities. In our work we paid attention to the necessity to estimate research abilities in the structure of the gnoseological component of the professional competence of future fitness-trainers.

The content of the praxeological component of the professional competence of future fitness-trainers is the complex of competences that reflect certain groups of specialists' professional functions. We related didactic-motor, projecting-designing, control-analytic, organizational-regulative, motivational-communicative and marketing-commercial subcompetences to them.

We related technical and physical readiness in aerobics, force fitness, aquaaerobics, pilates and so on; the ability to teach clients motor actions of healthy fitness types and recreation; ability to correct mistakes and give insurance and help; ability to choose specific methods and means of the development (education) of physical qualities (correction of psychophysiological states), including by using an equipment according to tasks, age and physical condition of clients, to the content of the didactic-motor subcompetence of future fitness-trainers.

The projecting-designing subcompetence of future fitness-trainers includes their integral ability to transform desires and aim of a client in the system of concrete learning-training tasks; the ability to form fitness-programs in aerobics, aquaaerobics, force fitness, mental fitness and so on, to develop animation programs with determining stages, aims, general and special tasks, means, equipment, rational parameters of the motor activity, forms of organization, methods of control, effectiveness criteria for persons of different age, sex, and physical condition; the ability to form prophylactic activities with physical exercises for persons with risk factors of diseases of the cardiovascular system, metabolism, locomotor system; ability to choose a musical accompaniment for complexes of physical exercises of different directionality if necessary.

The control-analytic subcompetence of future fitness-trainers provides their ability to realize the stage, operative and current analysis of the clients' health condition, their physical development, risk factors of diseases, functional state of the cardiovascular, respiratory systems of the organism, nervous-psychic status, physical readiness and working capacity of persons of different age and sex; ability to the correspondent interpretation of data, to revelation of technical and methodical mistakes.

The organizational-regulative subcompetence of future fitness-trainers characterizes their ability to realize the effective interaction between clients' group/client; ability to coordinate and to realize panned tasks at training, based on the optimal distribution of resources and regulation of load parameters; to provide the feedback with clients, based on means of verbal and non-verbal communication; to realize self-regulation of own psychophysiological condition. At the same time within this competence future fitness-trainers must be able to form individual financial documents of accounting and reporting; to check the usefulness of a special equipment and stock; give the first medical help at traumas and acute pathological states that may appear at fitness activities; to favor the positive emotional background at training by expressing artistry and pedagogical tact.

The motivational-communicative subcompetence of future fitness-trainers reflects one of important functions - the necessity to the purposeful formation of the clients' motivation to the regular physical activity and healthy life style. At the same time a fitness-trainer must give consultations of the wide circle of questions: safety of using the special equipment, rules of behavior in a club, principles of balanced and rational nutrition, methods of correction of harmful habits, self-control and so on. Within this subcompetence we accent just the future fitness-trainer's ability to manage the mo- 
tivational process of clients as opposite to the communicative competence as the ability to effective cooperation between participants of communication, declared by scientists [12, 17].

The marketing-commercial subcompetence of future fitness-trainers provides their ability to realize a series of marketing strategies, namely: to reveal client's key needs, to plan and to develop fitness-services, based on the previous analysis of the consumption market; elaboration and realization of the system of motivating potential and real consumers of fitness-services, self-presentation and presentation of own fitness-services, presentation work with a client, ability to conduct a commercial conversation with a client as to offering group and personal fitness-services and associated healthy ones. Separating the marketing-commercial subcompetence, we widen the circle of functions, necessary for a future fitness-trainer.

The estimation criterion of the praxeological component of the professional competence of future fitness-trainers is the operational-technological one, used for determining a degree of the future fitness-trainer's ability to execute professional functions. The indicator of this criterion is a degree of mastering the didactic-motor, projecting-designing, control-analytic, organizational-regulative, motivational-communicative and marketing-commercial subcompetences.

The personal component of the professional competence of future fitness-trainers provides the formation of the complex of professionally important personal qualities of future fitness-trainers. The socio-psychological criterion that characterizes certain socio-psychological personal qualities, determining the fitness-trainer's successful activity, is used for estimating the personal component. It includes the following indicators: empathy, communicative, organizational, leader abilities and conflict-resistance. Let's note that we didn't meet indications on the study of such personal qualities as leader abilities and conflict-resistance in works of scientists about the personal component of the professional competence of future fitness-trainers.

Thus, the presented qualitative signs of formation levels of each component of the professional competence of future fitness-trainers allow us to determine the integral characteristics of the high, middle and low formation levels of the professional competence of future fitness-trainers in higher educational institutions.

The high formation level of the professional competence of future fitness-trainers in higher educational institutions is characterized by: the brightly expressed striving to master professional knowledge and skills; strong desire to work as a fitness-trainer and to improve the qualification; stable manifestation of the ability to self-control of the behavior; brightly expressed initiativeness and persistence in achieving set tasks; brightly expressed personal striving for self-actualization: formation of values of a mature person, high need in knowledge, high creativity level, brightly expressed adherence to principles, adequacy of self-estimation and high level of contact talents; deep, strong and system knowledge in the cycle of professional disciplines; brightly expressed ability to realize the full volume of research abilities; brightly expressed manifestation of the didactic-motor, projecting-designing, control-analytic, organizational-regulative, motivational-communicative and marketing-commercial subcompetences with the ability to realize independently the full volume of fitness-trainer's functions with creativity elements, without mistakes, with effective actions in learning and real situations; stable manifestations of empathy abilities; stable manifestations of organizational and communicative abilities; bright manifestation of leader abilities; demonstration of tolerance in a conflict, essential manifestations of conflict resistance.

The middle formation level of the professional competence of future fitness-trainers in higher educational institutions is characterized by: the moderate striving to master professional knowledge and skills; moderate desire to work as a fitness-trainer and to improve the qualification; situational manifestations of initiativeness and persistence in achieving set tasks; moderate manifestations of the personal striving for self-actualization: mastering values of a mature person, moderate need in knowledge, middle creativity level; stable adherence to principles; optimal self-estimation with a tendency to underestimation, moderate manifestation of contact talents; presence of knowledge in the cycle of professional disciplines; ability to realize most of research abilities independently, rest - with teacher's help; expressed manifestation of the didactic-motor, projecting-designing, control-analytic, organizational-regulative, motivational-communicative and marketing-commercial subcompetences with the ability to realize independently the full 
volume of fitness-trainer's functions without creativity elements, with unessential mistakes, with effective actions in learning situations; situational manifestations of empathy; unstable manifestations of personal organizational and communicative leader abilities; moderate manifestations of conflict resistance.

The low formation level of the professional competence of future fitness-trainers in higher educational institutions is characterized by: the absence of striving to master professional knowledge and skills; absence of the desire to work as a fitness-trainer and to improve the qualification; weak manifestations of initiativeness and persistence in achieving set tasks; absence of manifestations of the personal striving for self-actualization: non-formed values of a mature person, absence of the need in knowledge, low creativity level; non-adherence to principles; low self-estimation, absence of a contact talents manifestation; fragmental knowledge in the cycle of professional disciplines; ability to realize research skills only with teacher's help; fragmental manifestation of the didactic-motor, projecting-designing, control-analytic, organizational-regulative, motivational-communicative and marketing-commercial subcompetences; ability to realize certain fitness-trainer's professional functions only with orienting on an example and teacher's help, with gross mistakes in learning and real situations; prevailing inability to empathy; absence of organizational and communicative leader abilities; low level of manifestations of conflict resistance.

\section{Conclusions}

1. The structure of professional competence of future fitness-trainers includes five components: motivational, axiological, gnoseological, praxeological and personal one. At that each component in the totality characterizes a certain personal property, ability or talent that is a direct or indirect fundament of the successful realization of professional functions.

2. The criteria and correspondent indicators of estimating formation of the professional competence of future fitness-trainers are: motivational-volitional (indicator - volitional self-regulation and professional directionality of a person), value-sense (indicator - striving for self-actualization), cognitive-intellectual (indicator - volume of knowledge from the cycle of professional subjects and research abilities), operational-technological (indicator - degree of didactic-motor, projecting-designing, control-analytic, organizational-regulative motivational-communicative and marketing-commercial subcompetences); and socio-psychological criterion (indicator - empathy, communicative, organizational, leader abilities and conflict-resistance).

3. There were separated the levels of the professional competence formation of future fitness-trainers: high, middle and low ones.

\section{References}

[1] Growth Curve (2017). Health Club Management, 247, 38-42. Available at: http://www. healthclubmanagement.co.uk/pdf/HCM_Jun_2017.pdf

[2] Recruitment \& Employment Confederation. Available at: https://www.rec.uk.com/

[3] Vasilenko, M. M. (2012). Spetsyfika pidhotovky maibutnikh fitnes-treneriv v Nimechchyni ta Avstrii (v porivnialnomu aspekti) [Specificity of training future fitness-trainers in Germany and Austria (in comparative aspect)]. Pedagogy formation of creative personality in higher and secondary schools, 26 (79), $126-131$.

[4] Vasylenko, M. (2016). Advantages and disadvantages of professional preparation of the future fitness trainers in Great Britain and Australia. EUREKA: Social and Humanities, 4, 47-54. doi: 10.21303/25045571.2016 .00137

[5] Rashkevych, U. M. (2014). Bolonskyi protses ta nova paradyhma vyshchoi osvity [The Bologna Process and the New Paradigm of Higher Education]. Lviv: Vydavnytstvo Lvivskoi politekhniky, 168.

[6] Zabloczka, O. S. (2008). Kompetentnist, kvalifikatsiia, kompetentsiia yak kliuchovi katehorii kompetentnisnoi paradyhmy vyshchoi osvity [Competence, qualification, competency as key categories of the higher education competence paradigm]. Zhytomyr Ivan Franko State University Journal, 39, 52-56.

[7] Markova, A. K. (1990). Psihologicheskiy analiz professionalnoy kompetentnosti uchitelya [Psychological analysis of teacher's professional competence]. Soviet pedagogy, 8, 82-88. 
[8] Shashkina, M. B., Semina, E. A. (2015). Klaster professional'no-profil'nykh kompetentsiy kak kompleks trebovaniy $\mathrm{k}$ rezul'tatu matematicheskoy podgotovki budushhego uchitelya matematiki v vuze [Cluster of vocational competencies as a set of requirements for the result of the mathematical preparation of the future teacher of mathematics at the university]. Scientific review. Pedagogical sciences, 3, 187-188. Available at: https://science-pedagogy.ru/ru/article/view?id=1438

[9] Le Deist, F. D., Winterton, J. (2005). What Is Competence? Human Resource Development International, 8 (1), 27-46. doi: 10.1080/1367886042000338227

[10] Tuning Educational Structures in Europe - TUNING. Available at: http://www.unideusto.org/ tuningeu

[11] Guschina, N. V., Nazarenko, L. D. (2009). Formirovanie professional'noy kompetentnosti budushego trenera po sportivnoy aerobike [Formation of professional competence of the future trainer on sports aerobics]. Ulyanovsk: UlGPU, 122.

[12] Ponomarov, V. O. (2010). Formuvannia profesiino-pedahohichnoi kompetentnosti maibutnoho trenera $\mathrm{z}$ atletychnoi himnastyky u protsesi fakhovoi pidhotovky [Formation of professional-pedagogical competence of the future trainer on athletic gymnastics in the process of professional training]. Zaporizhzhia, 20.

[13] Atamas, O. A. (2015). Formuvannia hotovnosti maibutnikh uchyteliv fizychnoi kultury do vprovadzhennia tekhnolohii ozdorovchoho fitnesu [Forming of readiness of future teachers of physical culture isto introduction of technologies of health fitness]. Kyiv, 23.

[14] Batishheva, M. R. (2009). Pidhotovka maibutnikh uchyteliv fizychnoi kultury do provedennia ozdorovchoi himnastyky ta fitnesu z divchatamy-starshoklasnytsiamy [Training of future teachers of physical culture for conducting of health gymnastics and fitness with girls]. Lugansk, 22.

[15] Slobozhaninov, P. A. (2017). Formuvannia profesiinoi kompetentnosti maibutnikh fakhivtsiv z fitnesu ta rekreatsii iz zastosuvanniam informatsiino-komunikatsiinykh tekhnolohii [Forming of professional competence of future specialists is on a fitness and recreation with application of informatively-communication technologies]. Kyiv, 22.

[16] Volkov, K. D. (2009). Formirovanie u budushhikh spetsialistov po fizicheskoy kul'ture i sportu spetsial'nykh professional'nykh kompetentsiy dlya raboty v ozdorovitel'nom fitnese [Formation of special professional competences for the future specialists in physical training and sports for work in health-improving fitness]. Moscow, 20.

[17] Shestakova, E. V. (2017). Design of a system for qualified staff training in fitness industry on the basis of a professional standard. Russian Journal of Entrepreneurship, 18 (16), 2377-2388. doi: 10.18334/ rp.18.16.38222

[18] Gladyshev, A. A. (2015). Formirovanie individual'noy obrazovatel'noy traektorii studentov fizkul'turno-sportivnogo profilya na osnove kompetentnostnogo podkhoda (dlya spetsializatsii v sfere fitnesa) [Formation of an individual educational trajectory of students of sports profile on the basis of a competence approach: specialization for fitness experts]. Nizhnevartovsk, 204.

[19] Erl, R. V., Behl, T. R. (2012). Osnovyi personalnoy trenirovki [Basics of personal training]. Kyiv: Olimpiyskaya literatura, 724. 